Dept. of Vet. Pathology Infection and Immunity (VPII), University of Bristol, Langford House.

\title{
INVESTIGATION OF CERTAIN PROINFLAMMATORY AND ANTIINFLAMMATORY CYTOKINE LEVELS IN THE GUT BIOPSIES OF CATS WITH INFLAMMATORY BOWEL DISEASE USING REALTIME PCR \\ (With 9 Tables and 7 Figures)
}

By

CHLOE R. HARKIN and NASHWA E. WALY*

* Corresponding Author: Dept. of Animal Medicine, Fac. of Vet. Med. University, Assiut, Egypt.

(Received at 7/3/2007)

\section{SUMMARY}

The aim of this study was to measure and quantify levels of some cytokines implicated in the immunopathogenesis in the gut biopsies of cats with inflammatory bowel disease (IBD) using real time polymerase chain reaction (PCR). Frozen duodenal biopsies were collected from cats referred for investigation of chronic vomiting and/or diarrhea $(n=3)$ that were diagnosed with IBD. Duodenal biopsies from control cats $(n=5)$ were examined for the expression of mRNA for pro-inflammatory cytokines IFN- $\gamma$, IL-12 and TNF- $\alpha$, and anti-inflammatory cytokines IL4 and IL-10 using real-time RT-PCR. There was no significant difference between levels of expression of different tested mRNA cytokines in the two groups of cats $(\mathrm{p}>0.05)$. These findings suggest that the immunopathogenesis of feline IBD involve different mechanisms from that of other studied species and does not follow the classic Th1/Th2 paradigm.

Key words: Real time PCR, Feline IBD, IL-10, IL-12, p40, p35, IFN- $\gamma$ and $T N F-\alpha$

\section{INTRODUCTION}

Inflammatory bowel disease is one of the most perplexing group of diseases of the gastrointestinal tract of cats. The disease is still idiopathic despite extensive research into human and canine IBD (Tams, 1993, 1996). Inflammatory bowel disease is not well defined in cats with 
respect to the criteria for diagnosis, stages of the disease activity and immunopathogenesis. The cause of the disease remains unknown but the central hypothesis for the development of IBD is the loss of tolerance to intestinal microfloral and/or dietary antigens (Cave 2003). Recent years have seen many advances in the definition of certain elements of the pathology of the gut in cases of feline IBD. Immune cell populations in the gut of cats with IBD have recently been published (Waly et al., 2004).

The aim of this study was to qualify and quantify a panel of cytokines produced by immune cells in the feline small intestine during the inflammatory process and in healthy controls. Characterisation of the cytokine profiles in the mucosa of cats with IBD is important as it will bring new insights and may explain certain aspects of the immunopathogenesis and of the feline IBD. It may also help in the development of therapeutic agents.

\section{MATERIALS and METHODS}

\section{Cats and Biopsies}

Duodenal biopsies were collected from cats that were referred to the feline centre, University of Bristol, Langford for investigation of chronic vomiting, diarrhoea and/or weight loss suggestive of IBD $(n=3)$. Samples from cats with no history of gastrointestinal disease were also collected and considered as controls $(n=5)$. These included a sample from a cat with liver disease, but with no evidence of gastrointestinal inflammation and samples obtained from cats that were infected with Chlamydia or feline Foamy Virus, a normally non-pathogenic virus in the cat. The IBD group was cats with history of vomiting and/or diarrhoea (Table 1) and histological evidence of infiltrative changes typical of IBD.

Food was withheld from cats 12 - 24 hours prior to endoscopy. Endoscopy was performed under general anaesthesia using a flexible gastroscope with $6 \mathrm{~mm}$ diameter insertion tube and $2 \mathrm{~mm}$ biopsy channel (Olympus gastrointestinal fibrescope GIF N30, Keymed). Before and after endoscopy the instrument was disinfected and the instrument channel was flushed with sterile saline then air. All biopsies were collected in cryotubes (Simport, Quebec, Canada, J3G 4S5), snap frozen in liquid nitrogen at the time of collection and then stored in at $80^{\circ} \mathrm{C}$ until use. 


\section{Real-time RT-PCR}

Real-time reverse transcriptase-polymerase chain reaction (RTPCR) was used for quantitative detection of mRNA for various cytokines in the duodenal biopsies collected from control cats and cats with IBD using $\mathrm{G}_{3} \mathrm{PDH}$ as an internal standard. The method and protocol had already been established and kindly provided by Dr Nguyen-Van (Nguyen Van et al., 2005). The method and protocol are briefly described below.

\section{RNA extraction}

Total RNA from biopsies was extracted using a RNeasy Mini Kit (Qiagen Sciences, Maryland, USA) according to the manufacturers manual. Three to four mucosal biopsies comprised the starting material for the extraction. Samples were kept at low temperature on ice throughout the ribolisation stage and biopsies were put in $500 \mu \mathrm{l}$ of lysis buffer RLT $(1 \mu 1 \beta$. ME to $100 \mu 1$ RLT) in the riboliser tube. Lysis was performed at $6 \mathrm{~m} / \mathrm{s}$ for 45 seconds with the Ribolyser system (Hybaid, Ashford, Middlesex, UK). To elute RNA, two aliquots of $40 \mu \mathrm{l}$ of RNase-free water was pippetted directly onto the rneasy silica membrance and centrifuged for $1 \mathrm{~min}$ at $8000 \times \mathrm{g}$.

\section{Genomic DNA elimination}

Two rounds of digestion were used to remove genomic DNA (gDNA) from the total RNA as the RT-PCR for detecting cytokine mRNA is sensitive to very small amounts of gDNA. The first step was using DNase in solution following the RNA purification step described above. Ten $\mu 1$ of DNase (1unit/ $\mu$ l, Promega) and $10 \mu \mathrm{l}$ (10x buffer) were added to the $80 \mu \mathrm{l}$ RNA collection tube and left at room temperature for 15 minutes. The tube was them mixed thouroughly with $350 \mu$ of RLT lysis buffer containing $1 \mu 1 \beta$-Mercapto-ethanol (ME). A total of $250 \mu 1$ of a $100 \%$ ethanol was added and to the collection tube and the total $700 \mu \mathrm{l}$ solution was immediately applied to an RNeasy column and centrifuged for 15 seconds at $8000 \times g$. The collection tube and the flowthrough were discarded and the RNA in the column was washed with $350 \mu \mathrm{l}$ buffer RW1 by centrifugation at $8000 \times g$ for 15 seconds.

The second step of elimination was an on-column DNase step performed with the RNase-free-DNase set (Qiagen, UK) following the manufacturer's recommendations. Elution of RNA was then performed twice with $40 \mu \mathrm{l}$ RNase-free water each time. The resulting $80 \mu \mathrm{l}$ of eluted RNA samples were stored at $-70^{\circ} \mathrm{C}$ until use. 


\section{cDNA synthesis}

The cDNA was synthesized using $9 \mu$ l of total RNA, reverse transcriptase (Improm-II, Promega, USA) and random hexamers in a Thermal Cycler (PTC-200, MJ Research, USA). The $9 \mu 1$ RNA sample was mixed with $1 \mu \mathrm{l}$ of random hexamer $(0.5 \mu \mathrm{g} / \mu \mathrm{l})$ in a $200 \mu \mathrm{l}$ thin wall tube (Bio-Rad Laboratories, Hercules, CA 94547) and heated for 5 minutes at $70^{\circ} \mathrm{C}$, then cooled to $4^{\circ} \mathrm{C}$. In the next step, a master mix of $4 \mu 1$ $5 \mathrm{x}$ buffer, $2.4 \mu \mathrm{l} 25 \mathrm{mM} \mathrm{MgCl}_{2}, 1 \mu 1$ 10nM dNTP, $1 \mu 1$ Improm-II reverse transcriptase (Promega, USA) and $1.6 \mu \mathrm{H} \mathrm{H}_{2} \mathrm{O}$ were added. The reverse transcription step consisted of 5 minutes at $20^{\circ} \mathrm{C}, 30$ minutes at $42^{\circ} \mathrm{C}$, 15 minutes at $70^{\circ} \mathrm{C}$, then cooled and held at $4^{\circ} \mathrm{C}$. The resulting $20 \mu 1$ cDNA was stored at $-70^{\circ} \mathrm{C}$ until use.

\section{Primer and probe design}

All the primers and probes used in this study were the kind gift of Dr Nguyen-Van (Nguyen Van et al., 2005). Sequences of primers and probes used in this study are summarized in Table 2.

\section{Real-time RT-PCR optimization}

Primers were reconstituted in $10 \mathrm{mM}$ Tris, $0.5 \mathrm{mM}$ EDTA pH9 to a concentration of $100 \mu \mathrm{M}$. Both the forward and reverse primers were diluted together to make a working solution with a final concentration of $10 \mu \mathrm{M}$ of each primer and then kept at $-20^{\circ} \mathrm{C}$.

Polymerase chain reaction amplification of each cytokine was performed using $5 \mu \mathrm{l}$ of sample cDNA and $12.5 \mu \mathrm{l}$ of $2 \mathrm{x}$ Hotstartaq master mix (Qiagen), $0.5 \mu 110 \mu \mathrm{M}$ primers, $1.5 \mu \mathrm{l}$ of $\mathrm{MgCl}_{2}(50 \mathrm{mM})$ and $2.5 \mu \mathrm{l}$ of Syber Green I (1:5000 in water). Nuclease-free water was used to adjust to a final volume of $25 \mu 1$. Amplification was performed in an iCycler iQ (Bio-Rad Laboratories Ltd.) at $95^{\circ} \mathrm{C}$ for 15 minutes, and then 45 cycles of $95^{\circ} \mathrm{C}$ for 10 seconds and $60^{\circ} \mathrm{C}$ for 15 seconds to amplify the product. Assays were optimized using Sybr Green I prior to the use of Taqman probes, which increase the specificity of each assay.

\section{Real-time RT-PCR performance with cDNA samples}

The cDNA was synthesized from each RNA sample in duplicate. A $130 \mu \mathrm{l}$ of AE buffer was added to $20 \mu \mathrm{l}$ of each cDNA sample to give a final volume of $150 \mu$, enough to perform all reactions in duplicate. Nuclease-free water was used as negative control and diluted gel purified cytokine and $\mathrm{G}_{3} \mathrm{PDH}$ PCR products were used in PCRs as positive controls. Each cytokine detection was conducted on a separate plate and a duplicate of each plate was run.

Amplification of each cytokine was performed using $5 \mu \mathrm{l}$ of diluted cDNA and $12.5 \mu \mathrm{l}$ of buffer $2 x$ Hotstartaq master mix (Qiagen), 
$0.5 \mu \mathrm{l}, 10 \mu \mathrm{M}$ primers, $1.5 \mu \mathrm{l}$ of $\mathrm{MgCl}_{2}(50 \mathrm{mM})$. All PCR assays were performed with probe concentrations of $100 \mathrm{nM}$, except TNF- $\alpha$ where a concentration of $200 \mathrm{nM}$ was used instead. Primer concentrations were kept the same as those used in the PCR with Sybr Green I. Nuclease-free water was used to adjust a final volume of $25 \mu$ l.

Amplification was performed in an iCycler iQ (Bio-Rad Laboratories Ltd.) at $95^{\circ} \mathrm{C}$ for 15 minutes, then 45 cycles of $95^{\circ} \mathrm{C}$ for 10 seconds and $64{ }^{\circ} \mathrm{C}\left(\mathrm{G}_{3} \mathrm{PDH}, \mathrm{IL}-12 \mathrm{p} 35\right)$ or $60^{\circ} \mathrm{C}(\mathrm{TNF}-\alpha)$ or $58^{\circ} \mathrm{C}$ (IL-4, IL-10, IL12p40 and IFN- $\gamma$ ) for 15 seconds.

\section{Normalisation}

A housekeeper gene $\left(\mathrm{G}_{3} \mathrm{PDH}\right)$ was used to normalize all of the threshold cycle $\left(C_{t}\right)$ values of other cytokine products. The correction value for $\mathrm{G}_{3} \mathrm{PDH}$ of each sample was calculated using the following equation:

$\mathrm{G}_{3} \mathrm{PDH}$ correction value $=$ mean sample $C_{t} \mathrm{G}_{3} \mathrm{PDH}$ value -20

The corrected cytokine $C_{t}$ value of each sample was calculated using the following equation:

Corrected cytokine $C_{t}$ value =mean cytokine $C_{t}-\mathrm{G}_{3} \mathrm{PDH}$ correction value

The relative number of cDNA copies in the sample was calculated using the following equation. Based on the maximum normalized $C_{t}$ value of all samples, it was assumed that a $C_{t}$ of 42 equaled one copy of cDNA.

Relative cytokine copy number $=2^{(42 \text {-corrected cytokine } C t \text { value })}$

\section{RESULTS}

Real-time RT-PCR of the RNA from $\mathrm{C} 1$ and $\mathrm{C} 7$ detected no DNA contamination. However, traces of DNA were detected in all of the remaining samples. After comparing the $\mathrm{C}_{t}$ values of RNA and cDNA for each sample, the $C_{t}$ value of $G_{3} P D H$ expression in RNA was always at least 11.2 cycles and in some cases up to 20 cycles higher than the expression in the corresponding cDNA sample. Working on the basis that for the addition of every three cycles the DNA content is approximately 100 -fold lower, 11.2 cycles difference would imply that the DNA content in the RNA sample was at least a million-fold lower than in the DNA sample. This indicates that there were only traces of genomic DNA in the RNA samples and this did not affect the detection efficiency of cytokine mRNA expression. The RNA samples were therefore reverse transcribed to cDNA. 


\section{Melting Curve for $\mathbf{G}_{3} \mathbf{P D H}$}

The melting temperature of the product was determined using a graph of the negative first differential of the relative fluorescence unit (RFU) vs. temperature. The melting curve was plotted by the iCycler software to verify that the correct DNA had been amplified. In the case of $\mathrm{G}_{3} \mathrm{PDH}$, with a melting temperature of $92^{\circ} \mathrm{C}$, the peak of the graph shows the melting point at $92^{\circ} \mathrm{C}$, confirming amplification of the correct product (Fig 1).

\section{IL-4}

The highest expression of IL-4 mRNA was found in C3, a control cat. The lowest expression was found in $\mathrm{C} 2$, another control cat. All values for the IBD group were within the range of the control group, with $\mathrm{C} 5$ expressing the most IL-4, and C7 expressing the least (Table 4; Fig 2). Figure 2 shows that the average of IL-4 mRNA expression in the duodenal biopsies was higher in control cats than IBD cats. The standard deviation (SD) was slightly higher in the control group, showing that the range of expression was larger in this group compared to the IBD group. The wide SD reflects an overlap in expression of IL-4 between control and IBD cats. There was no significant difference between the two groups with respect to IL-4 expression ( $p=0.4)$.

\section{IL-10}

The highest expression of IL-10 mRNA was found in C1, a control cat. The lowest expression was found in C6, one of the IBD group. However, C5 and C7 showed IL-10 expression within the range of expression of the control cats (Table 5; Fig 3). Figure 3 shows the average of IL-10 mRNA expression in the duodenal biopsies. IL-10 mRNA expression was slightly higher in control cats compared to IBD cats. The SD was higher in the IBD group, showing that the range of expression was greater in this group compared to the control group. The wide SD reflects an overlap in results between control and IBD cats for expression of IL-10. However, there was no significant difference between the two groups $(\mathrm{p}=0.5)$.

\section{IFN- $\gamma$}

The highest expression of IFN- $\gamma$ mRNA was found in $\mathrm{C} 4$, a control cat. There was no detectable expression in the C6 biopsy from the IBD group. However, C5 and C7 showed IFN- $\gamma$ expression within the range of expression of the control cats (Table 6; Fig 4). Figure 4 illustrates that the average of IFN- $\gamma$ mRNA expression in the duodenal biopsies was higher in controls compared to the IBD group. There was 
no significant difference between the two groups for IFN- $\gamma$ expression $(\mathrm{p}=0.4)$.

\section{IL-12p35}

The highest expression of IL-12p35 mRNA was found in C1, a control cat. However, there was no detectable expression in the $\mathrm{C} 2$ biopsy from the control group. The IBD group showed IL-12p35 expression within the range of expression of the control cats (Table 7; Fig 5). The average of IL-12p35 mRNA expression in the duodenal biopsies was higher in IBD cats compared to the control group and the $\mathrm{SD}$ was higher in the control group. Therefore, the range of IL-12p35 expression was greater in this group compared to the IBD group. There was no significant difference in IL-12p35 expression between the two groups $(\mathrm{p}=0.3)$.

\section{IL-12p40}

The highest expression of IL-12p40 mRNA was found in C6 from the IBD group. The lowest expression of IL-12p40 was found in the $\mathrm{C} 2$ biopsy from the control group. The rest of the IBD group ( $\mathrm{C} 5$ and C6) showed IL-12p40 expression within the range of expression of the control cats (Table 8; Fig 6). The average of IL-12p40 mRNA expression in the duodenal biopsies was slightly higher in IBD cats compared to the control group and the SD was higher in the control group. Therefore, the range of IL-12p40 expression was greater in this group compared to the IBD group. However, there was no significant difference between the two groups $(p=0.2)$.

\section{TNF- $\alpha$}

The highest expression of TNF- $\alpha$ mRNA was found in $\mathrm{C} 4$ (control cat). The lowest expression of TNF- $\alpha$ was found in the C6 biopsy from the IBD group. The rest of the IBD group (C5 and C6) showed TNF- $\alpha$ expression within the range of expression of the control cats (Table 9; Fig 7). The average of TNF- $\alpha$ mRNA expression in the duodenal biopsies was higher in control cats compared to the IBD group and the SD was higher in the control group. Therefore, the range of TNF- $\alpha$ expression was greater in this group compared to the IBD group. The SD demonstrates that TNF- $\alpha$ mRNA expression overlaps in both groups (Fig 7). There was no significant difference in TNF- $\alpha$ expression between the two groups $(\mathrm{p}=0.2)$. 
Fig. 1: Melting Curve for $\mathrm{G}_{3} \mathrm{PDH}$

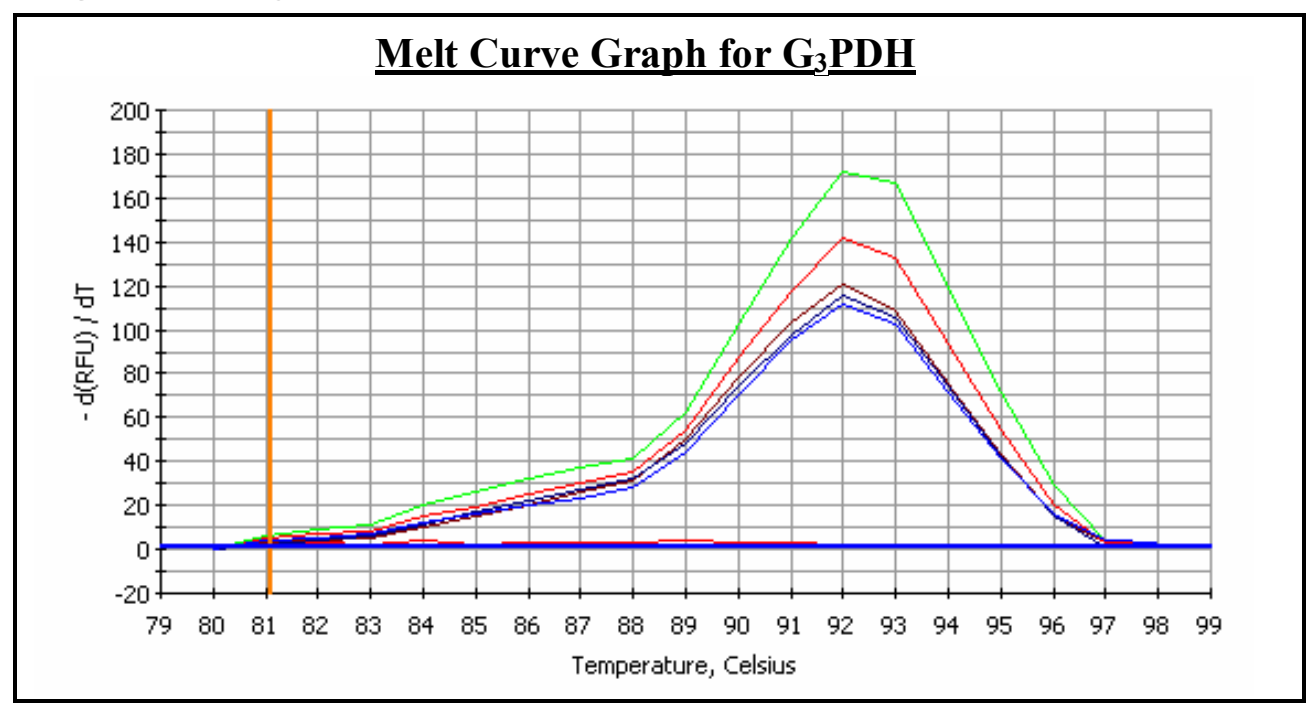

Real-time RT-PCR was used to measure $\mathrm{G}_{3} \mathrm{PDH}$ mRNA expression in all duodenal biopsies collected from control and IBD cats. The graph represents the negative first differential of the relative fluorescence unit (RFU) vs. temperature. The peak indicates the melting temperature, the point at which $50 \%$ of DNA molecules denature.

Fig. 2: Relative Copy Number $\left(\log _{10}\right)$ of IL-4 in the duodenal biopsies of Control and IBD cats.

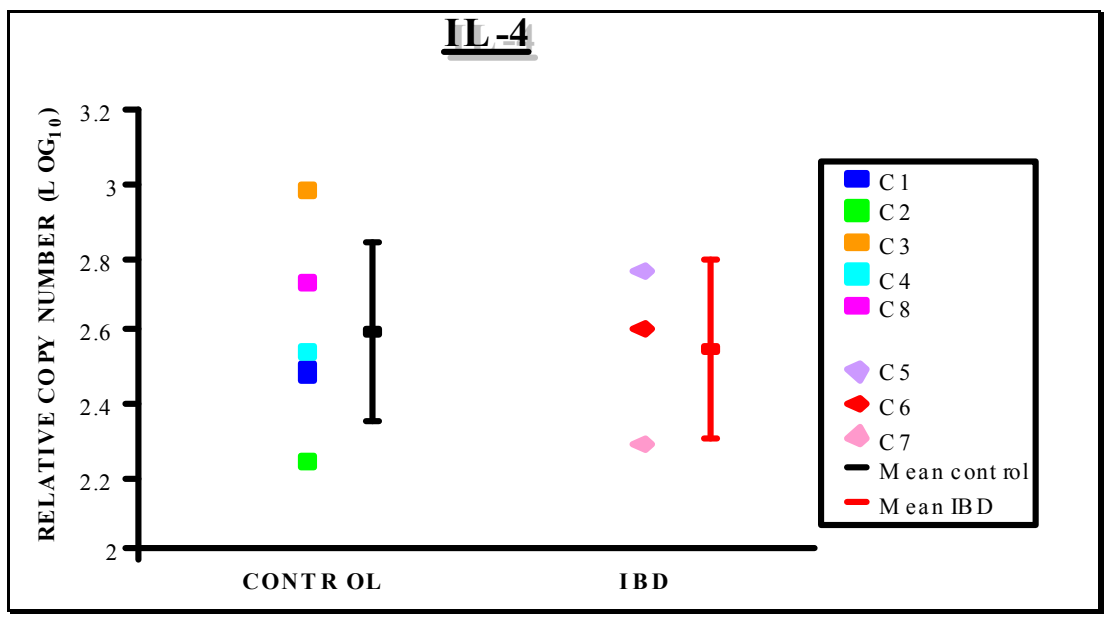

IL-4 mRNA expression was measured in duodenal biopsies collected from control and IBD cats. The points represent $\log _{10}$ of RCN of IL-4 in each sample for both groups and the mean $\mathrm{RCN}$ within each group. Error bars represent \pm SD of the RCN for both groups. 
Fig. 3: Relative Copy Number $\left(\log _{10}\right)$ of IL-10 in the duodenal biopsies of Control and IBD cats.

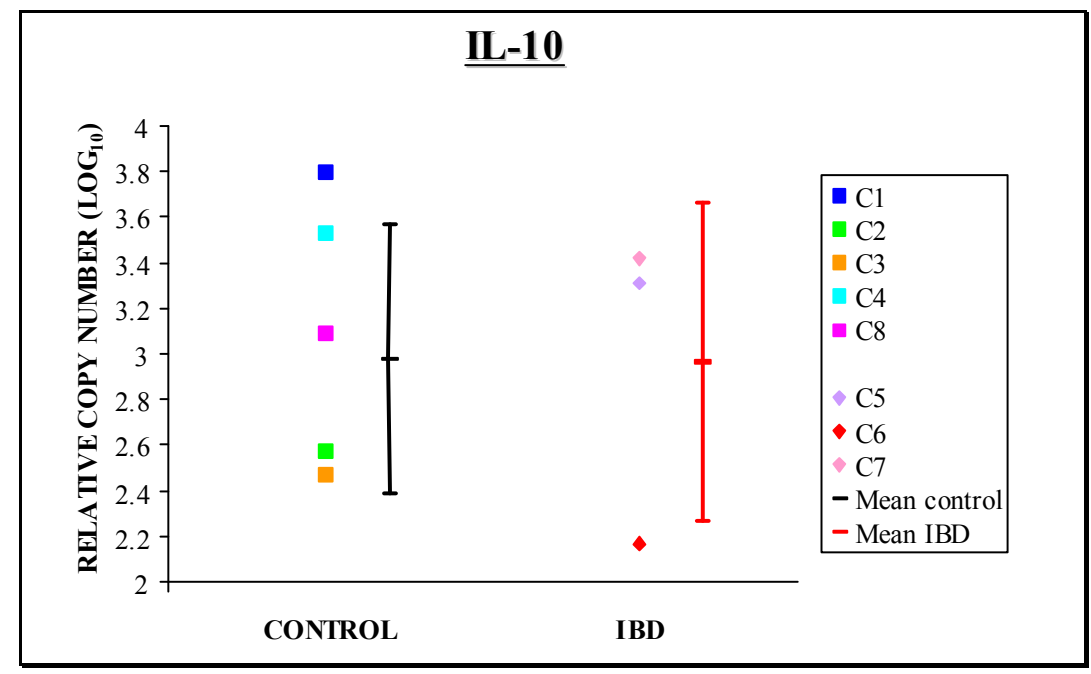

IL-10 mRNA expression was measured in duodenal biopsies collected from control and IBD cats. The points represent $\log _{10}$ of RCN of IL-10 in each sample for both groups and the mean RCN within each group. Error bars represent \pm SD of the RCN for both groups.

Fig. 4: Relative Copy Number $\left(\log _{10}\right)$ of IFN- $\gamma$ in the duodenal biopsies of Control and IBD cats.

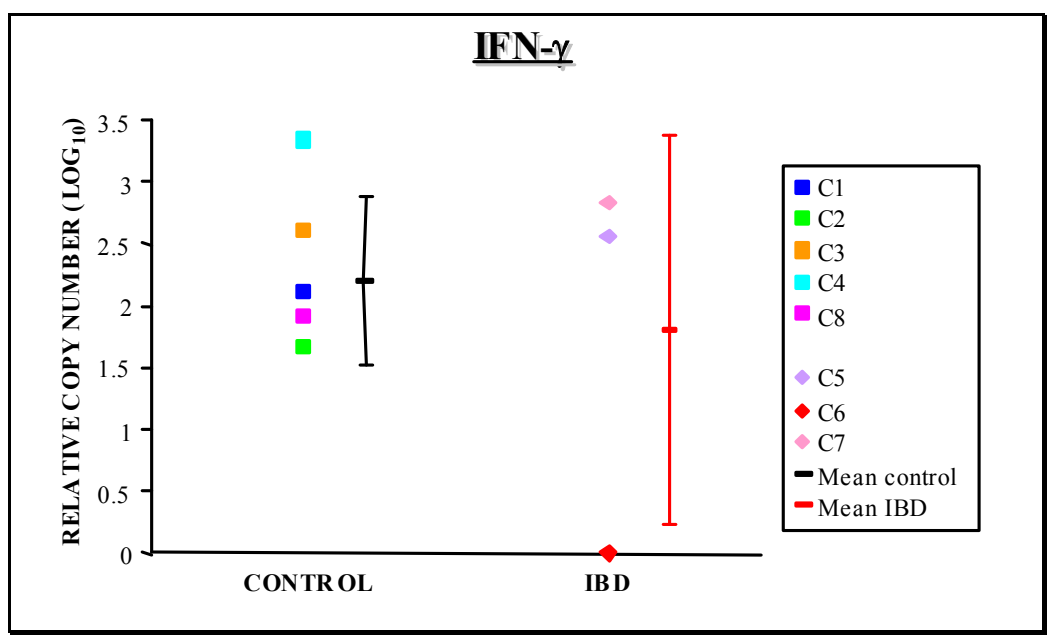

IFN- $\gamma$ mRNA expression was measured in duodenal biopsies collected from control and IBD cats. The points represent $\log _{10}$ of RCN of IFN- $\gamma$ in each sample for both groups and the mean RCN within each group. The bars represent \pm SD of the RCN for both groups. 
Fig. 5: Relative Copy Number $\left(\log _{10}\right)$ of IL-12p35 in the duodenal biopsies of Control and IBD cats.

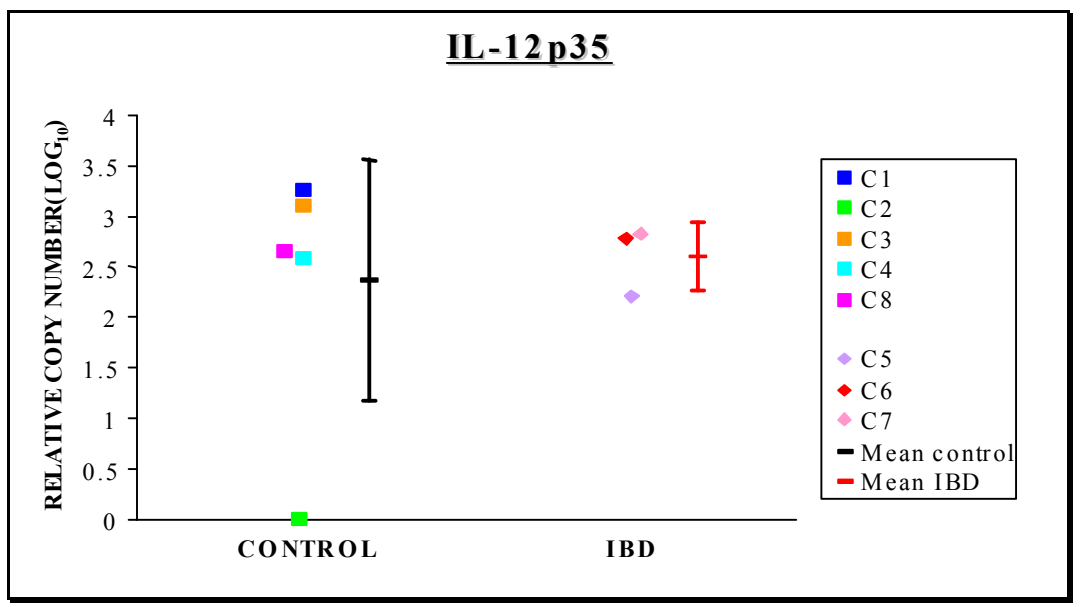

IL-12p35 mRNA copy number was measured in duodenal biopsies collected from control and IBD cats. The points represent the RCN $\left(\log _{10}\right)$ of IL-12p35 in each sample for both groups and the mean RCN within each group. The bars represent $\pm \mathrm{SD}$ of the RCN for both groups

Fig. 6: Relative Copy Number $\left(\log _{10}\right)$ of IL-12p40 in the duodenal biopsies of Control and IBD cats

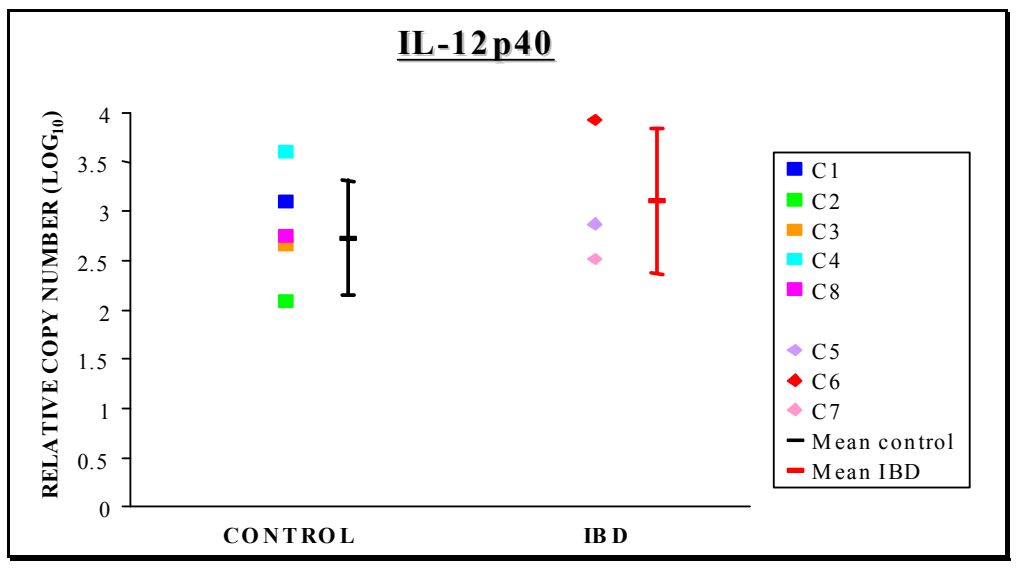

IL-12p40 expression was measured in duodenal biopsies collected from control and IBD cats. The points represent the $\log _{10}$ of RCN of IL-12p40 in each sample for both groups and the mean RCN within each group. The bars represent \pm SD of the RCN for both groups. 
Fig. 7: Relative Copy Number $\left(\log _{10}\right)$ of TNF- $\alpha$ in the duodenal biopsies of Control and IBD cats

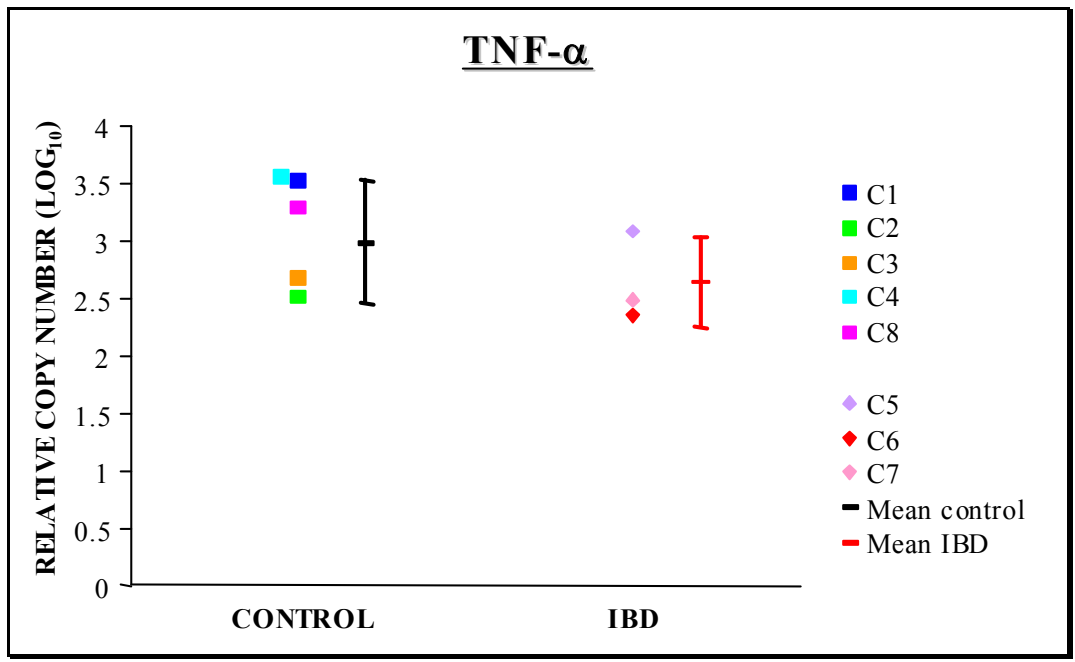

TNF- $\alpha$ mRNA copy number was measured in duodenal biopsies collected from control and IBD cats. The points represent $\log _{10}$ of RCN of TNF- $\alpha$ in each sample for both groups and the mean RCN within each group. The bars represent \pm SD of the RCN for both groups

Table 1: Clinical details of control and IBD cats

\begin{tabular}{cccccc}
\hline Case & Group & Age (years) & Breed & Sex & Diagnosis \\
\hline C1 & CONTROL & ND & DSH & F & CC \\
C2 & CONTROL & ND & DSH/ABY & F & CC \\
C3 & CONTROL & 1 & DSH & M & SPF \\
C4 & CONTROL & 1 & DSH & M & SPF \\
C5 & IBD & 0.5 & TKN & FN & IBD \\
C6 & IBD & 6 & DSH & FN & IBD \\
C7 & IBD & 1.6 & DSH & FN & IBD \\
C8 & CONTROL & ND & & & FV
\end{tabular}

$\mathrm{TKN}=$ Tonkinease, $\mathrm{DSH}=$ Domestic Shorthair, $\mathrm{F}=$ female, $\mathrm{FN}=$ neutered female, $\mathrm{M}=$ male $\mathrm{C}=$ Chlamydia felis infection, $\mathrm{FV}=$ foamy virus infection, $\mathrm{CC}=$ chronic conjunctivitis 
Table 2: Details of primer and probes used in real-time RT-PCR

\begin{tabular}{|c|c|c|c|c|}
\hline Cytokine & Forward primer $5^{\prime} \rightarrow 3^{\prime}$ & Reverse primer $3^{\prime} \rightarrow 5^{\prime}$ & Probe $5^{\prime} \rightarrow 3^{\prime}$ & $\begin{array}{r}\text { Optimal Annealing } \\
\text { Temperature }\left({ }^{\circ} \mathrm{C}\right)\end{array}$ \\
\hline $\mathrm{G}_{3} \mathrm{PDH}$ & $\begin{array}{l}\text { GCTGCCCAGAA } \\
\text { CATCATCC }\end{array}$ & $\begin{array}{l}\text { GTCAGATCCACG } \\
\text { ACGGACAC }\end{array}$ & N/A & N/A \\
\hline IL-4 & $\begin{array}{l}\text { CCCCTAAGAACA } \\
\text { CAAGTGACAAG }\end{array}$ & $\begin{array}{l}\text { CCTTTGAGGA } \\
\text { ATTTGGTGGAG }\end{array}$ & $\begin{array}{l}\text { TTCTGCAGAGCCAC } \\
\text { AACCGTGC }\end{array}$ & 58 \\
\hline IL-10 & $\begin{array}{l}\text { ACTTTAAGGGTT } \\
\text { ACCTGGGTTG }\end{array}$ & $\begin{array}{l}\text { CGTGCTGTTT } \\
\text { GATGTCTGG }\end{array}$ & $\begin{array}{l}\text { TTGGAGGAGGTGAT } \\
\text { GCCCCA }\end{array}$ & 58 \\
\hline TNF- $\alpha$ & $\begin{array}{c}\text { CACATGGCCTGC } \\
\text { TGCAACTAATC }\end{array}$ & $\begin{array}{l}\text { AGCTTCGGGG } \\
\text { TTTGCTACTAC }\end{array}$ & $\begin{array}{l}\text { CTCGAACTCCGAGT } \\
\text { GACAAGCCA }\end{array}$ & 60 \\
\hline IL-12p35 & $\begin{array}{c}\text { AATGTTCCAGTG } \\
\text { CСТCAACC }\end{array}$ & $\begin{array}{l}\text { CTAGAGTTTG } \\
\text { TCTGGCCTTCTG }\end{array}$ & $\begin{array}{l}\text { CTGCGAGCCATCAG } \\
\text { CAACCG }\end{array}$ & 64 \\
\hline IL-12p40 & $\begin{array}{l}\text { GCCTACCCATTG } \\
\text { AAGTCGTG }\end{array}$ & $\begin{array}{l}\text { GGTTTGATGA } \\
\text { TGTCCCTCATG }\end{array}$ & $\begin{array}{l}\text { 'TGCGAGCCATCAG } \\
\text { CAACACG }\end{array}$ & 58 \\
\hline IFN- $\gamma$ & $\begin{array}{c}\text { TGCAAGTAATCC } \\
\text { AGATGTAGCAG }\end{array}$ & $\begin{array}{l}\text { GTTTTATCACT } \\
\text { CTCCTCTTTCCAG }\end{array}$ & 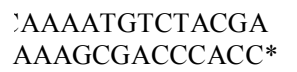 & 58 \\
\hline
\end{tabular}

*Anti-sense probe

Table 3: Correction values based on real-time RT-PCR results for $\mathrm{G}_{3} \mathrm{PDH}$ expression

\begin{tabular}{ccc}
\hline Case & Average $\mathrm{C}_{\mathrm{t}}$ & Correction to $\mathrm{C}_{\mathrm{t}}=20$ \\
\hline $\mathrm{C} 1$ & 24.25 & -4.25 \\
$\mathrm{C} 2$ & 23.55 & -3.55 \\
$\mathrm{C} 3$ & 23.95 & -3.95 \\
$\mathrm{C} 4$ & 18.85 & +1.15 \\
$\mathrm{C} 5$ & 19.75 & +0.25 \\
$\mathrm{C} 6$ & 26.95 & -6.95 \\
$\mathrm{C} 6$ & 21.80 & -1.80 \\
$\mathrm{C} 7$ & 20.00 & $+/-0$ \\
$\mathrm{C} 8$ & 18.75 & +1.25 \\
\hline
\end{tabular}

Table 4: Relative Copy Number $\left(\log _{10}\right)$ of IL-4 in Control and IBD cats

\begin{tabular}{cc}
\hline Case & $\mathrm{LOG}_{10}(\mathrm{RCN})$ \\
\hline $\mathrm{C} 1$ & 2.484 \\
$\mathrm{C} 2$ & 2.235 \\
$\mathrm{C} 3$ & 2.975 \\
$\mathrm{C} 4$ & 2.544 \\
$\mathrm{C} 5$ & 2.754 \\
$\mathrm{C} 6$ & 2.604 \\
$\mathrm{C} 7$ & 2.288 \\
$\mathrm{C} 8$ & 2.724 \\
\hline
\end{tabular}

The values represent $\log _{10}$ of RCN of IL-4 in the duodenal biopsies for each cat. The IBD group is highlighted with shading. 
Table 5: Relative Copy Number $\left(\log _{10}\right)$ of IL-10 in Control and IBD cats

\begin{tabular}{cc}
\hline $\begin{array}{c}\text { CASECa } \\
\text { se }\end{array}$ & $\mathrm{LOG}_{10}(\mathrm{RCN})$ \\
\hline $\mathrm{C} 1$ & 3.793 \\
$\mathrm{C} 2$ & 2.574 \\
$\mathrm{C} 3$ & 2.468 \\
$\mathrm{C} 4$ & 3.530 \\
$\mathrm{C} 5$ & 3.311 \\
$\mathrm{C} 6$ & 2.167 \\
$\mathrm{C} 7$ & 3.417 \\
$\mathrm{C} 8$ & 3.086 \\
\hline
\end{tabular}

The values represent $\log _{10}$ of RCN of IL-10 in the duodenal biopsies for each cat. The IBD group is highlighted with shading.

Table 6: Relative Copy Number $\left(\log _{10}\right)$ of IFN- $\gamma$ in Control and IBD cats

\begin{tabular}{cc}
\hline Case & $\mathrm{LOG}_{10}(\mathrm{RCN})$ \\
\hline $\mathrm{C} 1$ & 2.107 \\
$\mathrm{C} 2$ & 1.656 \\
$\mathrm{C} 3$ & 2.604 \\
$\mathrm{C} 4$ & 3.334 \\
$\mathrm{C} 5$ & 2.566 \\
$\mathrm{C} 6$ & 0.000 \\
$\mathrm{C} 7$ & 2.837 \\
$\mathrm{C} 8$ & 1.912 \\
\hline
\end{tabular}

The values represent $\log _{10}$ of RCN of IL-10 in the duodenal biopsies for each cat. The IBD group is highlighted with shading.

Table 7: Relative Copy Number $\left(\log _{10}\right)$ of IL-12p35 in Control and IBD cats

\begin{tabular}{cc}
\hline Case & $\mathrm{LOG}_{10}(\mathrm{RCN})$ \\
\hline $\mathrm{C} 1$ & 3.266 \\
$\mathrm{C} 2$ & 0.000 \\
$\mathrm{C} 3$ & 3.101 \\
$\mathrm{C} 4$ & 2.595 \\
$\mathrm{C} 5$ & 2.213 \\
$\mathrm{C} 6$ & 2.785 \\
$\mathrm{C} 7$ & 2.821 \\
$\mathrm{C} 8$ & 2.664 \\
\hline
\end{tabular}

The values represent the relative copy number $\left(\log _{10}\right)$ of IL-12p35 in the duodenal biopsies for each cat. The IBD group is highlighted with shading. 
Table 8: Relative Copy Number $\left(\log _{10}\right)$ of IL-12p40 in Control and IBD cats

\begin{tabular}{cc}
\hline CASE & LOG $_{10}(\mathrm{RCN})$ \\
\hline $\mathrm{C} 1$ & 3.11 \\
$\mathrm{C} 2$ & 2.09 \\
$\mathrm{C} 3$ & 2.66 \\
$\mathrm{C} 4$ & 3.60 \\
$\mathrm{C} 5$ & 2.87 \\
$\mathrm{C} 6$ & 2.51 \\
$\mathrm{C} 7$ & 2.88 \\
$\mathrm{C} 8$ & 2.75
\end{tabular}

The values represent $\log _{10}$ of RCN of IL-12p40 in the duodenal biopsies for each cat. The IBD group is highlighted with shading.

Table 9: Relative Copy Number $\left(\log _{10}\right)$ of TNF- $\alpha$ in Control and IBD cats

\begin{tabular}{cc}
\hline Case & $\mathrm{LOG}_{10}(\mathrm{RCN})$ \\
\hline $\mathrm{C} 1$ & 3.53 \\
$\mathrm{C} 2$ & 2.51 \\
$\mathrm{C} 3$ & 2.68 \\
$\mathrm{C} 4$ & 3.56 \\
$\mathrm{C} 5$ & 3.09 \\
$\mathrm{C} 6$ & 2.35 \\
$\mathrm{C} 7$ & 2.49 \\
$\mathrm{C} 8$ & 3.29 \\
\hline
\end{tabular}

The values represent $\log _{10}$ of RCN of TNF- $\alpha$ in the duodenal biopsies for each cat. The IBD group is highlighted with shading.

\section{DISCUSSION}

The aim of this study was to investigate the levels of a panel of cytokines produced by immune cells in the small intestine in IBD cats and in healthy controls. Duodenal biopsies from cats with IBD as well as healthy controls were examined for presence and quantification of the mRNA of IFN- $\gamma$, IL-4, IL-10, IL12p35, IL12p40 and TNF- $\alpha$.

Previous studies have reported that the level of IL-4 expression in mucosal biopsies of dogs with LPC was undetectable (Ridyard et al., 2002). Conversely, Locher et al. (2001) detected IL-4 in a few infiltrating cells of dogs with LPE or eosinophilic IBD compared to no 
detection in normal controls. Another report found increased IL-4 expression in German shepherd dogs with LPE (German et al., 2000). The results attained in this study are not in line with the findings in the dog. In this study, IL-4 mRNA expression was found in both control and IBD groups with no significant difference between groups. The results for IL-10 expression also opposes a recent report in which increased expression of IL-10 was found in the mucosa of healthy cats as opposed to cats with IBD (Nguyen-Van et al., 2006). However, the results correlate with a finding that the levels of IL-10 were unchanged in dogs with LPC (Ridyard et al., 2002). IL-4 and IL-10 are known to stimulate IgA production in vitro by cells of the gut-associated lymphoid tissue (GALT). The proposed immunopathogenesis of feline IBD is via the Th1 pathway, and therefore the results support the fact that IL-4 and IL10 expression (as part of the Th2 pathway) are not increased in IBD cats compared to controls. There is evidence from experimental studies that IL-10 would be a useful therapeutic agent in IBD (Kuhn et al., 1993).

Previous reports have shown that IFN- $\gamma$ production does not differ between active ulcerative colitis patients and healthy controls (Nakamura et al., 1992). The results of the present study are similar to those of a recent report (Nguyen Van et al., 2006) which also reported reduced levels of IFN- $\gamma$ mRNA expression in gut biopsies of cats with IBD. Other studies into cytokine mRNA expression in German shepherd dogs with lymphocytic plasmacytic enterocolitis (German et al., 2000) reported increased levels of IFN- $\gamma$ in the intestinal mucosa of diseased animals compared to healthy controls. Interferon- $\gamma$ is elevated in all genetic animal models of IBD and seems to be critical in the development of Th1 responses. The lack of significance in the results when comparing the two groups in our study as well as others (Nguyen Van et al., 2006) suggests that IFN- $\gamma$ doesn't play a role in feline IBD, and therefore, if Th1 responses are dependent upon this cytokine, feline IBD is unlikely to be caused by an immune response bias toward Th1 responses.

There was no significant distinction between the two groups with respect to IL-12 mRNA expression in the case of both subunits, interleukin-12p35 and IL-12p40. This finding is not dissimilar to other reports where IL-12 transcripts were found to be the least in feline gut biopsies (Nguyen Van et al., 2006). One of the control cats had no detectable expression of the p35 subunit which demonstrates the range of IL-12 expression possible in a healthy intestinal mucosa. There have 
also been reports of increased IL-12p40 expression in dogs with LPC (Ridyard et al., 2002), and GS dogs with LPE (German et al., 2000).

The results for TNF- $\alpha$ expression in this study contradict recent studies of cytokine mRNA extracted from mucosal biopsies of dogs with lymphoyctic plasmacytic colitis (Ridyard et al., 2002) and German shepherd dogs with lymphocytic plasmacytic enterocolitis (German et al., 2000) where up-regulation of TNF- $\alpha$ compared to normal dogs was found. Davidson et al. (2002) reported no detectable TNF- $\alpha$ in horses without IBD, but did detect expression in all cases of IBD.

As in human IBD, there are different forms of feline IBD such as lymphocytic plasmacytic enterocolitis, eosinophilic enteritis and granulomatous enterocolitis characterised by infiltration of different immune cells into the intestinal mucosa. In this study, the IBD group used were not defined for a particular type of feline IBD, and there is a possibility that the inflammation found in the duodenum was by different immune cells secreting different types of cytokines. Ulcerative colitis does not fit clearly into the Th1/Th2 paradigm, but does resemble a modified Th2 response when disease is established (Farrell \& Peppercorn, 2002). Therefore, the underlying pathology in the IBD group may have been different between cats and therefore it would be impossible to interpret a difference in cytokine mRNA expression when using an average of this group compared to the control group. For example, C6 showed no expression of IFN- $\gamma$ compared to high expression in the other two samples in the IBD group (Fig 4), but on the contrary showed high levels of IL-12p40 expression compared to the other samples in the group (Fig 6). These findings may suggest that the IBD may have been a result of a different type of immunopathogenesis.

An explanation of the similarity of mRNA expression between the two groups is that mRNA expression doesn't necessarily correspond to the amount of mRNA which is post-transcriptionally modified and eventually translated to protein (Brown 2002). Therefore, it would be reasonable to argue that even though the IBD cats transcribe similar amounts of cytokine mRNA to the control cats, it is important to note that cytokines detected as mRNA may not ultimately be expressed as proteins. In order to confirm that the mRNA expression found using RTPCR was related to the level of protein production, protein would need to be extracted from the biopsies and analysed by ELISA or Western blot. Although quantitative RT-PCR assays for many feline cytokines have been developed (Dean et al., 1998; Leutenegger et al., 1999), there are a lack of reagents suitable for these techniques which are dependent 
on the use of a high-quality antibody directed against the desired cytokine.

In this study, certain limitations exist regarding the choice of the control group and although there is a possibility that the cats with liver disease, Chlamydia Felis infection and Foamy Virus infection (a normally non-pathogenic organism in the cat) did not have problems associated with their gut, there is a chance that any underlying infection or disease could cause a sympathetic response in the intestinal mucosa. Therefore the results would not give a true interpretation of control cats when comparing them to cats with IBD.

Further work should be carried out on the expression of cytokine receptors in the intestinal mucosa with immunohistochemistry using antibodies towards specific cytokine receptors. Cytokine expression using a larger study population, looking at the both the mRNA and protein expression of different cytokines as possible in the intestinal mucosa should also be investigated.

\section{ACKNOWLEDGEMENT}

The Authors would like to thank Dr Chris Helps for advice and help with this work; Dr Karin Taglinger and Mr Nghia Van Ngyuen for supplying primers and probes used in this work.

\section{REFERENCES}

Brown, T.A. (2002): Genomes, Second Edition. BIOS Scientific Publishers Ltd., Oxford. Pages 325-328.

Cave, N.J. (2003): Chronic inflammatory disorders of the gastrointestinal tract of companion animals. New Zealand Veterinary Journal, 51 (6); 262-274.

Davidson, A.J.; Edwards, G.B.; Proudman, C.J.; Cripps, P.J. and Mathews, J.B. (2002): Cytokine mRNA expression pattern in horses with large intestinal disease. Research of Veterinary Science, 73 (3); 177-185.

Dean, G.A.; Higgins, J.; Lavoy, A.; Fan, Z. and Pederson, N.C. (1998): Measurement of feline cytokine gene expression by quantitative-competitive RT-PCR. Veterinary Immunology and Immunopathology, 63; 73-82.

Farrell, R. and Peppercorn, M. (2002): Ulcerative colitis. The Lancet, 359; 331-340. 
German, A.J.; Hall, E.J. and Day, M.J. (2000): Relative deficiency in IgA production by duodenal explants from german shepherd dogs with small intestinal disease. Veterinary Immunology and Immunopathology, 76; 25-43.

Kuhn, R.; Lohler, J.; Rennick, D.; Rajewesky, K. and Muller, W. (1993): Interleukin-10-deficient mice develop chronic enterocolitis. Cell, 75; 263-274.

Leuteneggar, C.M.; Mieslin, C.; Sigrist, B.; Ehrengruber, M.U.; Hoffmann-Lehmann, R. and Lutz, H. (1999): Quantitative realtime PCR for the measurement of feline cytokine mRNA. Veterinary Immunology and Immunopathology, 71; 291-299.

Locher, C.T.A.; Welle, M.; Busato, A.; Zubriggen, A. and Griot-Wenk, M.E. (2001): Quantitative assessment of mast cells and expression of $\operatorname{IgE}$ protein and mRNA for $\operatorname{IgE}$ and interleukin 4 in the gastrointestinal tract of healthy dogs and dogs with inflammatory bowel disease. American Journal of Veterinary Research, 62; 211-216.

Nakamura, M.; Saito, H.; Kasanuki, J.; Tamura, Y. and Ysohida, S. (1992): Cytokine production in patients with IBD. Gut, 33; 933-7.

Nguyen Van, N.; Taglinger, K.; Helps, C.R.; Tasker, S.; Gruffydd-Jones, T.J. and Day, M.J. (2006): Measurement of cytokine mRNA expression in intestinal biopsies of cats with inflammatory enteropathy using quantitative real-time RT-PCR. Veterinary Immunology and Immunopathology; 113: 404-414.

Ridyard, A.E.; Nuttal, T.J.; Else, R.W.; Simpson, J.W. and Iller, H.R. (2002): Evaluation of Th1, Th2 and immunosuppressive cytokine mRNA expression within the colonic mucosa of dogs with idiopathic lymphocytic-plasmacytic colitis. Veterinary Immunology and Immunopathology, 86; 205-214.

Tams, T.R. (1993): Feline Inflammatory Bowel Disease. Veterinary Clinics of North America, 23 (3); 569-586.

Tams, T.R.. (1996): Inflammatory bowel disease. In: Handbook of Small Animal Gastroenterology, Todd R. Tams (Editor), $1^{\text {st }}$ Edition, W.B. Saunders Co., Philaderlphia, USA, pp: 274-308.

Waly, N.E.; Stokes, C.R.; Gruffydd-Jones, T.J. and Day, M.J. (2004): Immune cell populations in the duodenal mucosa of cats with inflammatory bowel disease. Journal of Veterinary Internal Medicine, 18, 113-122. 